Limnetica, 28 (2): 185-188 (2009). DOI: 10.23818/limn.28.14

(C)Asociación Ibérica de Limnología, Madrid. Spain. ISSN: 0213-8409

AIL $\overparen{\rho}$

\title{
New records of Eunapius fragilis (Leidy, 1851) and Ephydatia fluviatilis (Linnaeus, 1759) (Porifera, Spongillidae) in Ebro River Basin (N Spain)
}

\author{
Javier Oscoz ${ }^{1, *}$, Pedro Tomás ${ }^{2}$ and Concha Durán ${ }^{3}$ \\ ${ }^{1}$ Departamento de Zoología y Ecología, Facultad de Ciencias, Universidad de Navarra, Apdo. 177 E-31080, \\ Pamplona, Navarra, España. \\ ${ }^{2}$ Laboratorio de Ensayos Técnicos S.A., Polig. Ind. Valdeconsejo, C/ Aneto, Parcela 8-A, E-50410 Cuarte de \\ Huerva, Zaragoza. \\ 3 Área Calidad de Aguas, Confederación Hidrográfica del Ebro, Paseo Sagasta 24-28, E-50071, Zaragoza. \\ * Corresponding author: joscoz@alumni.unav.es
}

Received: 17/3/09

Accepted: 21/4/09

\begin{abstract}
New records of Eunapius fragilis (Leidy, 1851) and Ephydatia fluviatilis (Linnaeus, 1759) (Porifera, Spongillidae) in the Ebro River Basin (N Spain)

This note represents a contribution to the knowledge of the presence of some species of freshwater sponges (Porifera, Spongillidae) in the Ebro River Basin. Two species (Eunapius fragilis and Ephydatia fluviatilis) collected in four rivers were identified. The presence of Eunapius fragilis in the Iberian Peninsula was confirmed comparing spicules measurements with existing literature data.
\end{abstract}

Key words: Freshwater sponges, Eunapius fragilis, Ephydatia fluviatilis, Ebro River Basin

\section{RESUMEN}

Nuevas citas de Eunapius fragilis (Leidy, 1851) y Ephydatia fluviatilis (Linnaeus, 1759) (Porifera, Spongillidae) en la cuenca del río Ebro (N España)

Esta nota representa una contribución al conocimiento sobre la presencia de algunas especies de esponjas dulceacuícolas (Porifera, Spongillidae) en la cuenca del río Ebro. Se identificaron dos especies (Eunapius fragilis y Ephydatia fluviatilis), las cuales fueron halladas en cuatro ríos. Mediante la comparación de los tamaños medidos de las espículas con los datos existentes en la literatura, se confirmó la presencia de Eunapius fragilis en la Peninsula Ibérica.

Palabras clave: Esponjas dulceacuícolas, Eunapius fragilis, Ephydatia fluviatilis, Cuenca del río Ebro.

Sponges (Porifera) are ancient multicellular animals that have colonized most aquatic habitats, from polar seas to tropical waters. The majority of sponges are restricted to marine environments, but a few taxa live in freshwater habitats. All freshwater sponges were combined into a new haplosclerid suborder Spongillina, comprising seven families: Spongillidae, Lubomirskiidae, Malawispongiidae, Metaniidae, Metschni- kowiidae, Palaeospongillidae and Potamolepidae (Manconi \& Pronzato, 2002). The Palaeospongillidae is exclusively fossil. Spongillidae show a worldwide distribution, whereas the other five families are endemic or are geographically restricted. According to Pronzato \& Manconi (2001) three families are present in Europe: Malawispongiidae (endemic to the lake Ochrid in Macedonia), Metschnikowiidae (endemic to 
the Caspian Sea) and Spongillidae (cosmopolitan and widely distributed). In the Iberian Peninsula four living sponges have been recorded (Traveset, 1986; Pronzato \& Manconi, 2001): Ephydatia fluviatilis (Linnaeus, 1759), Ephydatia muelleri (Lieberkühn, 1855), Heteromeyenia baileyi (Bowerbank, 1863) and Spongilla lacustris (Linnaeus, 1759). Moreover, Trochospongilla horri$d a$ (Weltner, 1893) has been recorded as a fossil sponge in Portugal, and on the other hand the presence of Eunapius fragilis (Leidy, 1851) is doubtful (Traveset, 1986). Due to relative scarcity of data about the presence of freshwater sponges, their discovery and identification could be con- sidered interesting in order to increase the knowledge of their distribution.

During the 2007 and 2008 water quality surveys carried out in the Ebro River Basin, several specimens of freshwater sponges were found in eight sample stations belonging to four rivers. However, due to the absence of gemmules in some of these specimens, only specimens from four localities in four rivers could be identified.

- Ephydatia fluviatilis (Fig. 1): This cosmopolitan sponge, widely distributed throughout the northern Hemisphere, is notably common in Europe and the Iberian Peninsula, both in

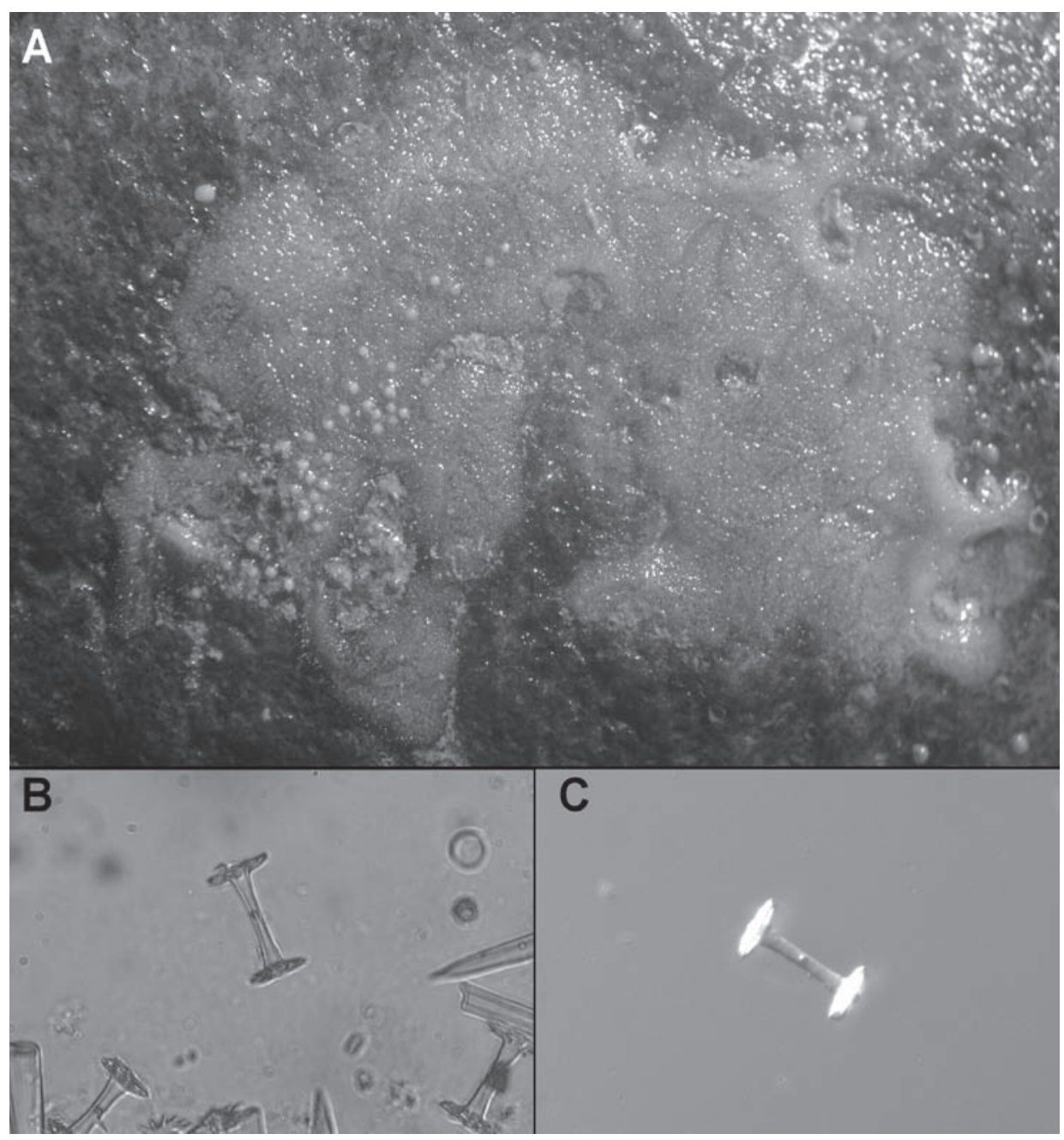

Figure 1. Ephydatia fluviatilis from Ebro River Basin. A: Specimen with gemmules; B and C: Gemmuloscleres. Ephydatia fluviatilis de la Cuenca del río Ebro. A: Individuo con gémulas; B y C: Gemoscleras. 
running and still waters (Traveset, 1986). It was found in two sample stations: Epila, lower Jalon River (2008-07-08) [UTM: 30T XM 422076] and Alfaro, in the lower Alhama River (2008-08-11) [UTM: 30T XM 024705].
All the specimens were found on boulders from lotic areas (riffles).

- Eunapius fragilis (Fig. 2): This sponge is cosmopolitan in a wide range of lentic and lo-

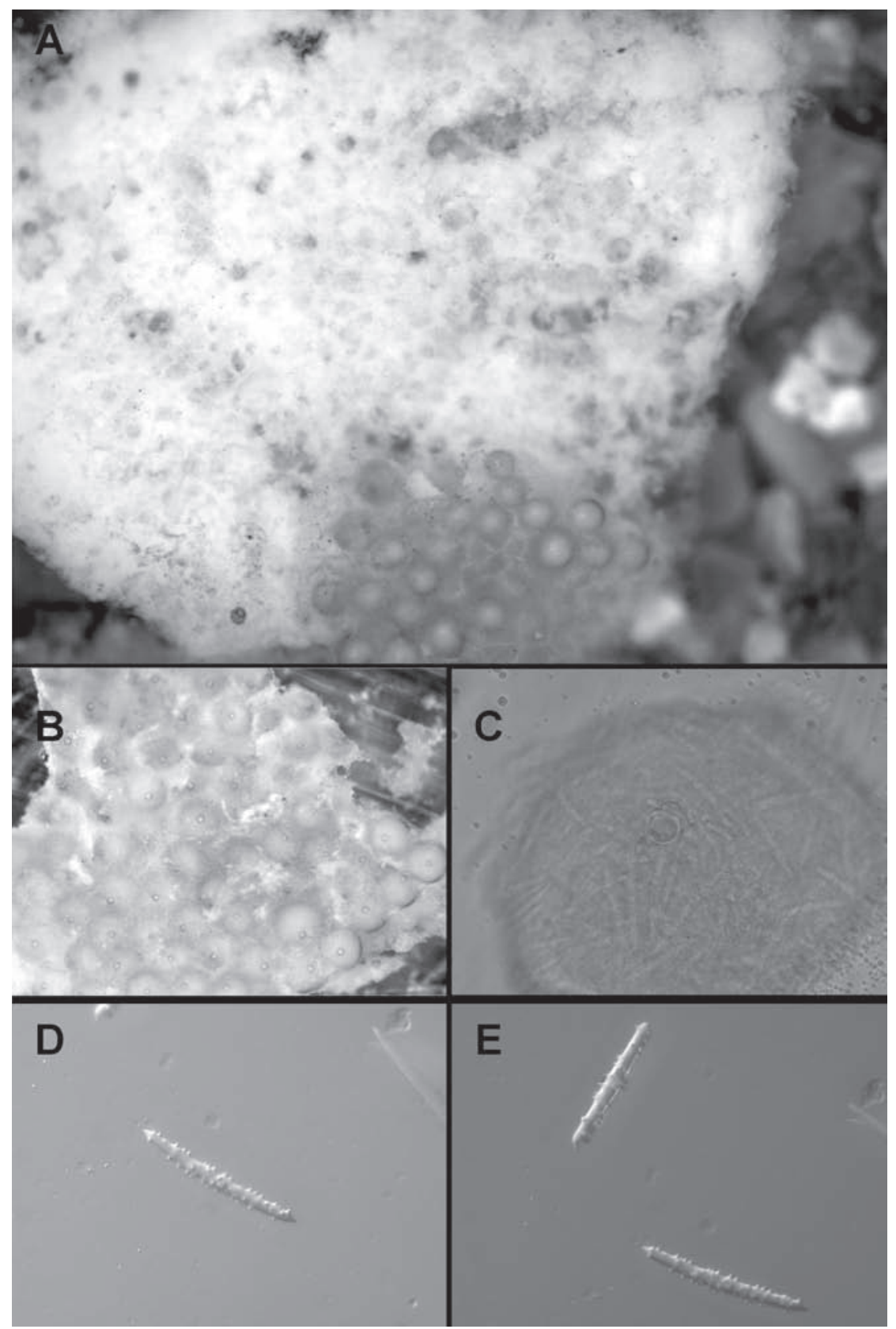

Figure 2. Eunapius fragilis from Ebro River Basin. A: Specimen with gemmules; B: Carpet of gemmules; C: Gemmule with foramen; D and E: Gemmuloscleres. Eunapius fragilis de la Cuenca del río Ebro. A: Individuo con gémulas; B: Grupo de gémulas; C: Gémula con foramen; D y E: Gemoscleras. 
tic habitats in Europe. It was cited in Portugal by Mathes (1952), but Traveset (1986) pointed out that its presence in the Iberian Peninsula was doubtful, and according to Pronzato \& Manconi (2001) this species was not present in the Iberian Peninsula. Specimens of this species were found in two close sample stations: Miranda de Ebro, in the lower Zadorra River (2008-08-20) [UTM: 30T WN 085251] and Miranda de Ebro, in the middle Ebro River (2008-08-20) [UTM: 30T WN 073245]. In the Zadorra River the specimen was found on a small boulder from a riffle, whereas in the Ebro River the sponge was found on an empty Trichoptera case in a river stretch dominated by runs and riffles. At least 30 megascleres and 40 gemmoscleres were measured in each specimen. Most of the measured spicules agreed with the ranges reported in the literature for this species (Pronzato \& Manconi, 2001). In the specimen from the Zadorra River, megascleres measured 174 to $224 \mu \mathrm{m}$ in length and averaged $204 \mu \mathrm{m}$, whereas gemmoscleres measured 62 to $150 \mu \mathrm{m}$ and averaged $87 \mu \mathrm{m}$ in length. In the specimen from the Ebro River, megascleres measured 195 to $232 \mu \mathrm{m}$ in length and averaged $218 \mu \mathrm{m}$, whereas gemmoscleres measured 70 to $132 \mu \mathrm{m}$ and averaged $83 \mu \mathrm{m}$ in length.

\section{ACKNOWLEDGMENTS}

We are grateful to Dr. Iosune Uriz (Centre d'Estudis Avançats de Blanes-CSIC), Dr. Renata Manconi (Università degli Studi di Sassari) and Dr. Roberto Pronzato (Università degli Studi di Genova) for the comments and help given, and for their kindness. We also thank Dr. Enrique Baquero (Universidad de Navarra) for his assistance in preparing the microscope photographs.

\section{REFERENCES}

MANCONI, R. \& R. PRONZATO. 2002. Suborder Spongillina subord. nov.; Freshwater sponges. In: Systema Porifera: A Guide to the Classification of Sponges, Vol. 1. J.N.A. Hooper \& R.W.M. Van Soest (eds.): 921-1019. Kluwer Academic/Plenum Publishers, New York.

MATHES, E. 1952. Guia de trabalhos prácticos de Zoologia. Acta Universitatis Coimbrigensis, 1952. $425 \mathrm{pp}$.

PRONZATO, R. \& R. MANCONI. 2001. Atlas of European freshwater sponges. Ann. Mus. civ. St. Nat. Ferrara, 4: 3-64.

TRAVESET, A. 1986. Clave de identificación de las esponjas de agua dulce de la Península Ibérica. Asociación Española de Limnología. Claves de identificación de la flora y fauna de las aguas continentales de la Península Ibérica. Publicación $N^{\circ}$ 2, 25 pp. 